\title{
SEASONAL VARIATION OF THE FLAVONOIDS PINOCEMBRIN AND 3-O-METHYLGALANGIN, IN THE SURFACE COMPONENT MIXTURE (RESINOUS EXUDATES AND WAXY COATING) OF HELIOTROPIUM STENOPHYLLUM
}

\author{
BRENDA MODAK*I, RENÉ TORRES, ALEJANDRO URZÚA \\ ${ }^{\prime}$ Natural Product Laboratory, Department of Environmental Sciences, Faculty of Chemistry and Biology, University of Santiago de Chile, \\ Av. Bernardo O'Higgins 3363, Santiago, Chile. \\ (Received: October 6, 2010 - Accepted: March 14, 2011)
}

\begin{abstract}
In this report we study the seasonal variation of the flavonoids pinocembrin and 3-O-methylgalangin in the surface component mixture (resinous exudate and waxy coating) of Heliotropium stenophyllum. The quantitative analysis of the flavonoids was performed using high-performance liquid chromatography of samples collected monthly over a whole year. The results showed an increase in the spring and summer yield of surface components and a decrease during the winter. Although the sum of pinocembrin and 3-O-methylgalangin did not follow a pattern related with hydric stress, UV radiation or high temperature during the year, a relationship between pinocembrin and 3-O-methylgalangin was found. On average during the months of September to August, excluding March, the amount of pinocembrin decreased wile the amount of 3-O-methylgalangin increased. The results suggest that the above compounds may play different ecophysiological functions during plant development and are consistent with the biosynthetic relationship between the two compounds.
\end{abstract}

Keywords: Heliotropium stenophyllum, surface components, seasonal variation pinocembrin, 3-O-methylgalangin.

\section{INTRODUCTION}

Heliotropium (Heliotropiaceae) section Cochranea (Miers) Reiche is found groing in the Pacific coastal region of Chile (Regions III-V). This is of particular ecological interest because, like many plants of this particular geographic area, they characteristically produce surface components (resinous exudates and waxy coating) that cover both leaves and stem $^{1}$. The resinous exudates are bio-synthesized in special glands (trichomes) populating the entire surface of these plants aerial structures ${ }^{1}$.

The epicuticular components of these species are characterized by the presence of flavonoids and, in some cases, aromatic geranyl derivatives. Flavonoids and aromatic geranyl derivatives have been reported in Heliotropium filifolium $^{2,3,4}, \mathrm{H}$. huascoense ${ }^{5,6}, \mathrm{H}$. glutinosum $^{7}{ }^{7}, \mathrm{H}$. taltalense and $H$. sclerocarpum ${ }^{9}$ and only flavonoids were found in: H. sinuatum ${ }^{10,11}, H$. chenopodiaceum ${ }^{12}$ and $H$. megalantum ${ }^{5}$.

We previously reported that Heliotropium stenophyllum Hook et Arn.,contains a mixture of : 2-geranyl-4-hydroxyphenyl acetate and the flavonoids: 5,7-dihydroxyflavanone (pinocembrin) (1) (Figure 1); 5,7-dihydroxy-3-methoxyflavone (3-O-methylgalangin) (2) (Figure 1); 5,7,4'-trihydroxyflavanone (naringenin); 5,4'-dihydroxy-7-methoxyflavanone (sakuranetin); 3,5,7-trhihydroxyflavanone (galangin); 3,7,4'-trihydroxy5,3'-dimethoxyflavone (5,3'-di-O-methylquercetin); 4'-acetoxy-5-hydroxy7-methoxyflavanone (4'-O-acetylsakuranetin) and 5,3',4'-trihydroxy-7methoxyflavanone (7-O-methyleriodictyol), in which pinocembrin (1) and 3-O-methylgalangin (2) accounted for around $80 \%$ of the mixture of surface components and the other flavonoids and 2-geranyl-4- hydroxyphenyl acetate were only found in minute amounts ${ }^{13,14}$.

Surface components from plants from arid and semi arid regions are of interest due to the well documented ecophysiological roles of these compounds. External flavonoids protect plants from UV radiation, high temperature and hydric stress, and some show antimicrobial and antifeedant properties. In addition, the epicuticular coating of leaves and stems protects the plants from light, temperature, osmotic stress, physical damage, altitude and pollution ${ }^{15,16,17}$.

In this report we studied the seasonal variation of two principal components, the flavonoids pinocembrin (1) and 3-O-methylgalangin (2) in the surface component mixture (resinous exudate and waxy coating) of Heliotropium stenophyllum. The quantitative analysis of the flavonoids was performed using high-performance liquid chromatography with samples collected monthly over a whole year.

\section{MATERIAL AND METHODS}

Plant Material

We monitored a population of Heliotropium stenophyllum that grows in Los Vilos, $4^{\circ}$ Region, Chile ( $31^{\circ} 52^{\prime}$ S, $\left.71^{\circ} 29^{\prime} \mathrm{W}\right)$. From September 2006 until August 2007. The population was divided into three groups and representative samples were obtained from individuals of each group. The pooled samples of each group (three samples) were used for further analysis. Voucher specimens were deposited in the Herbarium of the National History Museum Santiago, Chile (ST2560).

\section{Preparation of plant extract}

The total fraction of components from the surface of each sample of $H$. stenophyllum was obtained by dipping the whole fresh plant material in cold dichloromethane for 30 seconds. The extracts were filtered and concentrated to yield solid residues. They were frozen at $-20^{\circ} \mathrm{C}$ until HPLC analysis.

\section{HPLC Analysis}

Portions of $1 \mathrm{mg}$ of the resin were dissolved in $5 \mathrm{~mL}$ of methanol and were directly injected $(25 \mu \mathrm{l})$ in an HPLC (Merck-Hitachi L 6200) using a reversephase Lichrosorb RP-18 column (5 $\mu \mathrm{m}$ particle size; $21 \times 0.4 \mathrm{~cm})$. Gradient elution was performed using a mobile phase consisting of methanol (solution A) and 5\% acetic acid in $\mathrm{H}_{2} \mathrm{O}$ (solution B) as follows: $0-8 \mathrm{~min}$, isocratic elution with $30 \% \mathrm{~A} / 70 \% \mathrm{~B} ; 8-45$ min, linear gradient from $30 \% \mathrm{~A} / 70 \% \mathrm{~B}$ to $99 \% \mathrm{~A}$ / 1\% B. Detection was accomplished with a UV visible Merck-Hitachi L-4250 detector. Quantification was based on peak areas in chromatograms taken at $287 \mathrm{~nm}$ for pinocembrin and $340 \mathrm{~nm}$ for 3-O-methylgalangin. A dilution series of standard solutions was prepared from stock solutions of pinocembrin and 3-O-methylgalangin, and all solutions of standards and samples were stored at $5{ }^{\circ} \mathrm{C}$. Calibration lines were obtained by plotting peak areas against the concentrations of the standards; these lines were used to determine the concentrations of pinocembrin and 3-O-methylgalangin in the samples. Each sample was analyzed in triplicate.

\section{Statistical analysis}

All samples were analyzed in triplicate, and mean values were used for calculation. The results were expressed as the mean \pm standard deviation. Significant differences $(\mathrm{P}<0.05)$ were determined by one-way analysis of variance (ANOVA).

For the analysis of the production of the surface compounds the Moving Averages Method for three points was used. 


\section{RESULTS AND DISCUSSION}

The average amount of surface compounds in the monthly collected samples is shown in table 1 . These values, taken together with those observed in the moving averages (Table 2) show a clear seasonal pattern in their yield. There is an increased production of surface compounds in the spring-summer season (Southern Hemisphere), except in January $(\mathrm{P}<0.05)$, with a considerable decrease in fall-winter (particularly during the May-July quarter).

The highest yield of surface compounds in the spring-summer period can be related to UV radiation, high temperature, hydric stress and increased pressure from herbivorous insects. Therefore, the increase in external compound production is consistent with a protective mechanism against aggressive biotic and abiotic environmental conditions ${ }^{15,16,17}$.

Table 1. Seasonal variation of the surface compounds in the monthly collected samples from Heliotropium stenophyllum.

\begin{tabular}{|l|c|}
\hline \multicolumn{1}{|c|}{$\begin{array}{c}\text { Time of plant } \\
\text { collection }\end{array}$} & $\begin{array}{c}\text { \% of surface component mixture in } \\
\text { relation to the mass of fresh plant } \pm \text { s.d }\end{array}$ \\
\hline September & $5.99 \pm 0.09$ \\
\hline October & $6.76 \pm 0.22$ \\
\hline November & $6.01 \pm 0.21$ \\
\hline December & $7.17 \pm 0.18$ \\
\hline January & $5.97 \pm 0.11$ \\
\hline February & $7.76 \pm 0.20$ \\
\hline March & $7.56 \pm 0.25$ \\
\hline April & $4.74 \pm 0.27$ \\
\hline May & $3.06 \pm 0.08$ \\
\hline June & $3.10 \pm 0.11$ \\
\hline July & $3.56 \pm 0.33$ \\
\hline August & $4.92 \pm 0.71$ \\
\hline \multicolumn{2}{|c|}{ S.d: standard desviation }
\end{tabular}

Table 2. Moving average for the surface compounds in the monthly collected samples from Heliotropium stenophyllum.

\begin{tabular}{|l|c|}
\hline \multicolumn{1}{|c|}{ Quarter } & $\begin{array}{c}\text { Moving average for the surface } \\
\text { compounds }\end{array}$ \\
\hline Sept-Oct-Nov & 6.25 \\
\hline Oct-Nov-Dec & 6.65 \\
\hline Nov-Dec-Jan & 6.38 \\
\hline Dec-Jan-Feb & 6.97 \\
\hline Jan-Feb-Mar & 7.10 \\
\hline Feb-Mar-Apr & 6.69 \\
\hline Mar-Apr-May & 5.12 \\
\hline Apr-May-Jun & 3.63 \\
\hline May-Jun-Jul & 3.24 \\
\hline Jun-Jul-Aug & 3.86 \\
\hline Jul-Aug-Sep & 4.82 \\
\hline Aug-Sep-Oct & 5.89 \\
\hline
\end{tabular}

Flavonoid biosynthesis is activated by plants as response to UV radiation ${ }^{18}$ and their accumulation has been demonstrated to serve, among other roles, as a protective shield to leaves preventing molecular and cellular damage ${ }^{15}$. For example, 4,5-dihydroxy-3,6,7,8-tetramethoxyflavone and 4,5-dihydroxy3,6,7,8,3'-pentamethoxyflavone, natural compounds in Gnaphalium luteoalbum, significantly increase their concentration in leaves after UV-B radiation exposure ${ }^{19}$.

In the sampled habitat, an average precipitation of $160 \mathrm{~mm}$ per year is concentrated during the months of May to August ${ }^{20}$ and UV radiation is dramatically higher from September to April ${ }^{20,21,22}$. An average ozone decline of $2.5 \%$ per decade has been estimated for the band from $30^{\circ}$ to $50^{\circ}$ in the southern hemisphere ${ }^{23}$ where Los Vilos is located $\left(31^{\circ} 52^{\prime} \mathrm{S}\right)$. With these factors in mind and following the line of thought that climate, in particular UV radiation, governs flavonoid biosynthesis in plants, a large amount of flavonoids on the surface of leaves and stems of Heliotropium stenophyllum would be expected during the months of September to April.

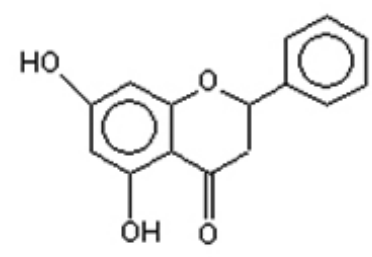

1<smiles>COc1c(-c2ccccc2)oc2cc(O)cc(O)c2c1=O</smiles>

2
Figure 1: Structures of pinocembrin (1) and 3-O-methylgalangin (2).

Although the sum of pinocembrin (1) and 3-O-methylgalangin (2) does not increase in those months and does not follow a clear pattern related to the dramatic variation of the climate data (table 3), a relationship between pinocembrin (1) and 3-O-methylgalangin (2) was found. On average during the months of September to August, with the exception of March, while the amount of pinocembrin (1) decreases, the amount of 3-O-methylgalangin increases (2), figure 2. These results are consistent with the biosynthetic relationship between the two compounds. Pinocembrin (1) is a key intermediate in the 3-O-methylgalangin (2) biosynthesis pathway in plants, with two enzymes involved flavanone 3 - $\beta$-hydroxylase and flavonol synthase ${ }^{24}$, which can be triggered by several biotic and abiotic factors that regulate the relationship between the two flavonoids. This consideration suggests that the above compounds may play different ecophysiological functions during the plant development.

Table 3. Amount of the flavonoids pinocembrin and 3-O-methylgalangin in the monthly collected samples from Heliotropium stenophyllum.

\begin{tabular}{|c|c|c|}
\hline $\begin{array}{l}\text { Time of plant } \\
\text { collection }\end{array}$ & $\begin{array}{c}\text { Concentration of } \\
\text { pinocembrin }(\mathrm{mM}) \pm \\
\text { s.d } \times 10^{-3}\end{array}$ & $\begin{array}{l}\text { Concentration of } \\
\text { 3-O-methylgalangin } \\
(\mathrm{mM}) \pm \mathrm{s.d} \times \mathbf{1 0}^{-3}\end{array}$ \\
\hline September & $0.151 \pm 2.86$ & $0.116 \pm 4.91$ \\
\hline October & $0.151 \pm 2.54$ & $0.065 \pm 4.01$ \\
\hline November & $0.172 \pm 1.01$ & $0.066 \pm 4.54$ \\
\hline December & $0.212 \pm 3.52$ & $0.109 \pm 2.86$ \\
\hline January & $0.177 \pm 5.71$ & $0.130 \pm 6.71$ \\
\hline February & $0.141 \pm 3.92$ & $0.141 \pm 7.82$ \\
\hline March & $0.255 \pm 5.56$ & $0.118 \pm 4.68$ \\
\hline April & $0.117 \pm 6.57$ & $0.268 \pm 5.21$ \\
\hline May & $0.098 \pm 2.90$ & $0.218 \pm 6.02$ \\
\hline June & $0.098 \pm 3.07$ & $0.252 \pm 6.15$ \\
\hline July & $0.073 \pm 3.4$ & $0.182 \pm 5.98$ \\
\hline August & $0.121 \pm 6.92$ & $0.222 \pm 7.32$ \\
\hline
\end{tabular}

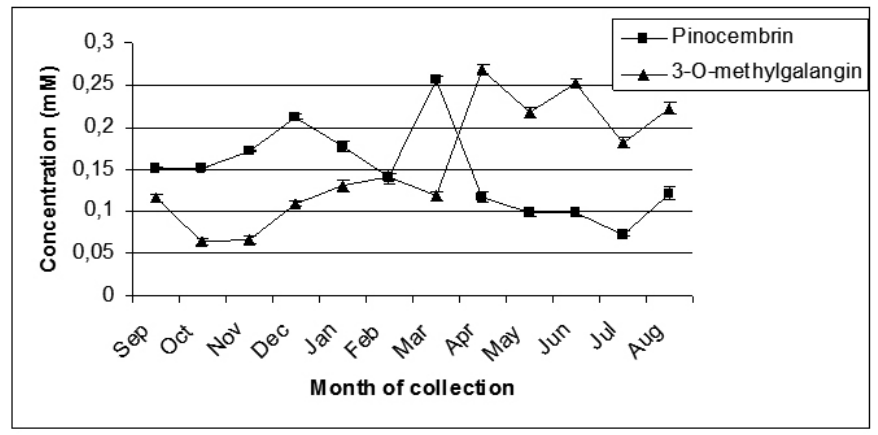

Figure 2: Seasonal variation of the amount of pinocembrin and 3-O-methylgalangin in the surface compounds in the monthly collected samples from Heliotropium stenophyllum. 
As a matter of fact it has been shown that pinocembrin (1) isolated from Flourencia oolepis demonstrates a strong antifeedant activity against Epilachna paenulata, Xanthogaleruca luteola and Spodoptera frugiperda ${ }^{25}$. In addition, the pinocembrin (1) action mechanism in Epilachna paenulata is chronic intoxication, rather than simple starvation from antifeedant effects ${ }^{26}$. Taking into account the above, the pinocembrin (1) amount increase during spring and summer months can be associated with a defence mechanism resulting from the increased pressure of herbivorous insects that occurs in those months.

Also, the high yield of 3-O-methylgalangin (2) in the winter can be associated with the protection of leaves from cold temperatures. Indeed, it has been reported that low winter temperatures can result in increased leaf flavonoid content; as suggested by the presence of increased mRNA content of phenylpropanoid pathway enzymes. A strong correlation between flavonoid content and tolerance to freezing has been recently reported in Arabidopsis thaliana, thus providing the first evidence that flavonoids may play a functional role in plant cold resistance ${ }^{27}$.

In conclusion, our results demonstrate that in Heliotropium stenophyllum the production of surface components (resinous exudates and waxy coating) is in response to changes in climatic factors and their yield follows a clear seasonal pattern.

On the contrary, there is no increase of flavonoid production in leaves and stems triggered by the UV-B radiation exposure from September to April. The observed variation of pinocembrin (1) and 3-O-methylgalangin (2) (Figure 2), consistent with the biosynthetic relationship between the two compounds, suggests they play different ecophysiological functions during the plant development.

\section{ACKNOWLEDGMENTS}

This work was supported by FONDECYT Grant No 1070121.

\section{REFERENCES}

1. J.M. Johnston, Contributions from the Gray Herbarium of Harvard University. Cambridge, 1928.

2. A. Urzua, L. Villarroel, R. Torres, S. Teillier, Biochem. System. Ecol, 21, $744,(1993)$.

3. A. Urzúa, B. Modak, R. Torres, Bol. Soc. Chil. Quím, 46, 175, (2001).

4. R. Torres, L. Villarroel, A. Urzúa, F. Delle Monache, G. Delle Monache, E. Gacs-Baitz, Phytochem, 36, 249, (1994).

5. A. Urzúa, B. Modak, L. Villarroel, R. Torres, L. Andrade, L.Mendoza, M. Wilkens, Bol. Soc. Chil. Quim, 45, 23, (2000).
6. L. Villarroel, R. Torres, A. Urzúa, M. Reina, R. Cabrera, A. GonzálezColoma, J. Nat. Prod, 64, 1123, (2001)

7. B. Modak, M. Rojas, R. Torres, J. Rodilla, F.Luebert, Molecules, 12,1057, (2007).

8. B. Modak, M. Rojas, R. Torres, Molecules, 14, 1980, (2009).

9. B. Modak, M. Salinas, J.Rodilla, R. Torres, Molecules, 14, 4625, (2009).

10. R. Torres, B. Modak, L. Villarroel, A. Urzúa, F. Delle Monache, F.Sanchez-Ferrando, Bol.Soc. Chil.Quím, 41, 195, (1996).

11. B. Modak, R. Torres, E. Lissi, F. Delle Monache, Nat. Prod. Res., 17, 403, (2003).

12. A. Urzúa, B. Modak, L. Villarroel, R. Torres, L. Andrade, Biochem.Syst. Ecol, 26, 127, (1998).

13. L. Villarroel, A. Urzúa, Bol.Soc. Chil. Quím, 35, 309, (1990).

14. L. Villarroel, R. Torres, A. Urzúa, Bol.Soc. Chil. Quim, 36, 169, (1991).

15. K. S. Gould, C. Lister, "Flavonoid function in Plants", Chapter 8, in: Flavonoids; Chemistry, Biochemistry and Applications. Ed. O. Yvind, M. Andersen, K. R. Markham. Taylor and Francis, New York, USA, (2006).

16. L. M. Schoonhoven, J. J. A van Loon, M. Dicke, "Insect-Plant Biology" (Chapter 6, Host-plant selection: how to find a host plant). Oxford University Press, New York, USA, (2005).

17. M. Riederer, C. Müller, "Biology of Plant Cuticle", Annual Plant Reviews, Vol 23. Blakwell Publishing, USA, (2006).

18. E. Logemann, A. Tavernaro, W. Schulz, E.I. Somssich, K. Hahlbrock, Proc. Natl. Acad. Sci. USA, 97, 1903, (2000).

19. P. Cuadra, J. Harborne, P.G. Waterman, Phytochemistry, 45,1377, (1997).

20. C. A. Fuentes, "Zonación de Regímenes Hídricos Mediante Índices Bioclimáticos de la Zona Comprendida Entre la III y X Región" Memoria de Título, Universidad de Chile, Santiago, Chile, (2007).

21. S. Cabrera, S. Bozzo, H. Fuenzalida, J. Photochem. Photobiol., 28, 137, (1995).

22. R.R. Cordero, P. Roth, A. Georgiev, L. DaSilva, Ener. Conv. Management, 46, 2907, (2005).

23. N. Chaves, J. C. Escudero, C. Gutierrez-Merino, J. Chem. Ecol., 23, 579, (1997).

24. I. Miyahisa, N. Funa, Y. Ohnishi, S. Martens, T. Moriguchi, S. Horinouchi, Appl. Microbiol. Biotechnol, 71, 53 (2006).

25. G. N. Diaz-Napal, M.C. Campinella, S. M. Palacios, Bioresour. Biotechnol., 100, 3669, (2009).

26. G. N. Diaz-Napal, M.T. Defagó, G. R. Valladares, S. M. Palacios, J. Chem. Ecol., 36, 898, (2010).

27. M. Korn, S. Petereck, H. Mock, A. Heyer, D. Hincha, Plant Cell Environ, 31,813, (2008). 